\title{
Leaf Blotching in Caladium (Araceae) Is Under Simple Genetic Control and Tightly Linked to Vein Color
}

\author{
Zhanao Deng ${ }^{1}$ and Brent K. Harbaugh \\ University of Florida, IFAS, Environmental Horticulture Department, \\ Gulf Coast Research and Education Center, 14625 County Road 672, \\ Wimauma, FL 33598
}

Additional index words. Caladium $\times$ hortulanum, leaf characteristics, inheritance, breeding, ornamental aroids

\begin{abstract}
Cultivated caladiums (Caladium $\times$ hortulanum Birdsey) are valued as important pot and landscape plants because of their bright, colorful leaves. Improving leaf characteristics or generating new combinations of these characteristics has been one of the most important breeding objectives in caladium. A major leaf characteristic in caladium is leaf blotching, the presence of numerous irregularly shaped color areas between major veins on leaf blades. This pattern of coloration in combination with bright colors has resulted in the popularity of a number of caladium cultivars. In this study, controlled crosses were made among three blotched and six nonblotched caladium cultivars. Their progeny were analyzed to understand the mode of inheritance of leaf blotching and its genetic relationship with the color of main leaf veins. Progeny of selfing nonblotched or crossing nonblotched cultivars were all nonblotched; selfing blotched cultivars (Carolyn Whorton, White Christmas, and Florida Blizzard) or crossing 'Florida Blizzard' and 'Carolyn Whorton' resulted in a 3:1 ratio (blotched:nonblotched); and progeny from crosses between blotched and nonblotched cultivars segregated in a 1:1 ratio (blotched:nonblotched). These results indicate that leaf blotching is controlled by a single nuclear locus with two alleles ( $B$ and $b$ ). $\chi^{2}$ analysis of the joint segregation between leaf blotching and vein color $(V)$ in five crosses showed that the blotching allele $B$ is linked to the green vein allele $V^{\text {g. ' }}$ Carolyn Whorton', 'White Christmas', and 'Florida Blizzard' are heterozygous for leaf blotching, and their genotype for leaf blotching and vein color $\left(V^{\mathrm{r}}, V^{\mathrm{w}}\right.$, and $V^{\mathrm{g}}$ for red, white, and green veins, respectively) are $V^{\mathrm{r}} b / / V^{\mathrm{g}} B, V^{\mathrm{g}} b / / V^{\mathrm{g}} B$, and $V^{\mathrm{w}} b / / V^{\mathrm{g}} B$, respectively. This information will be valuable for planning crosses and breeding populations to develop new blotched caladium cultivars. The information gained in this study may be helpful for understanding the inheritance of similar traits in other aroids.
\end{abstract}

Cultivated caladiums (Caladium $\times$ hortulanum Birdsey) are members of the aroid family and have been important pot and landscape plants (Evans et al., 1992). They are known for their bright and colorful leaves, adaptation to tropical and subtropical environmental conditions, and low landscape maintenance requirements. Caladiums are believed to have resulted from intra- or interspecific hybridization among several species that originated from the New World's tropical regions, including $C$. bicolor (Aiton) Vent., C. marmoratum Mathieu, C. picturatum C. Koch, and C. schomburgkii Schott (Birdsey, 1951; Hayward, 1950; Wilfret, 1993). They are diploids with $2 n=2 x=30$

Received for publication 30 Sept. 2008. Accepted for publication 4 Nov. 2008.

This research was supported by the Florida Agricultural Experiment Station and a grant from USDA/CSREES/TSTAR program.

We thank Richard O. Kelly, Joyce Jones, Nancy West, and Gail Bowman for their excellent technical support.

${ }^{1}$ To whom reprint requests should be addressed; e-mail zdeng@ufl.edu.
(Deng and Harbaugh, 2006; Wilfret, 1986). The presence of leaf spots is controlled by a single locus with two alleles that are inherited independently from leaf shape but closely linked with the color of the main vein (Deng et al., 2008).

Another major foliar trait in caladium is leaf blotching, the occurrence of numerous irregularly shaped color areas between major veins on leaf blades. Leaf blotches may appear singly or coalesce to large areas of coloration, up to several inches on mature leaves. This pattern of coloration in combination with bright colors has resulted in attractive, highly valued and desired caladium cultivars, including Carolyn Whorton and White Christmas. With large pink or white blotches, 'Carolyn Whorton' and 'White Christmas' have been the most popular fancy-leaved pink or white cultivars (Bell et al., 1998; Deng et al., 2005). Interest in incorporating this coloration pattern into new cultivars has been strong, but information on the inheritance of this trait has been lacking.

Leaf blotches as well as color bands or stripes are common in several aroids and have resulted in diverse and intriguing foliar coloration patterns in these plants (Henny, 1988). These coloration patterns have been a major contributing component to the ornamental and/or economic value of a number of important ornamental aroids (Henny and Chen, 2003). For example, the occurrence of white bands, silvery light gray or graygreen blotches, and silvery stripes in various portions of leaves has resulted in a number of distinct coloration or variegation patterns in several aglaonema species (Aglaonema Schott) (Henny, 1986). Dieffenbachia (Dieffenbachia Schott) cultivars often have leaf areas in different shades of green, yellow, cream, and white or combinations of these colors. Controlled crosses and segregation analysis in aglaonema and dieffenbachia have shown that the inheritance of some of these patterns is controlled by nuclear loci with multiple alleles (Henny, 1982, 1983, 1986).

The objectives of this study were to understand the mode of inheritance of leaf blotching in caladium, to determine the genetic relationship between leaf blotching and vein color, another important foliar trait for caladium, and to infer the genotype of important caladium cultivars for leaf blotching.

\section{Materials and Methods}

been made in recent years to gain a better understanding of the inheritance of foliar traits. These efforts have resulted in a number of findings. For example, it has been found that the three main leaf shapes in caladium (fancy or heart-shaped, strap or linearshaped, and lance, an intermediate between fancy and strap) are controlled by a single locus with two codominant alleles $(F$ and $f$ ) (Wilfret, 1986). The three main vein colors (red, white, and green) are determined by a single locus with three alleles $\left(V^{\mathrm{r}}, V^{\mathrm{w}}\right.$, and $\left.V^{\mathrm{g}}\right)$ that are independent from the leaf shape locus
Plant material. Three blotched ('Carolyn Whorton', 'White Christmas', and 'Florida Blizzard') and six nonblotched ('Candidum', 'Fannie Munson', 'Frieda Hemple', 'Gingerland', 'Miss Muffet', and 'Rosebud') commercial cultivars were used as parents in 20 crosses. 'Carolyn Whorton' and 'White Christmas' have pink and white blotches, respectively. 'Florida Blizzard' is a progeny 'White Christmas' (Harbaugh et al., 2002) of a cross between 'Aaron' (nonblotched) and 
and has inherited the blotching trait from 'White Christmas'. 'Candidum', 'Fannie Munson', 'Frieda Hemple', 'Gingerland', 'Miss Muffet', and 'Rosebud' are all nonblotched, but their leaves are in different colors (white with green veins, pink, red, white with red spots, lemon green with burgundy spots, and pink, respectively). All of these cultivars have been asexually propagated for many years (except 'Florida Blizzard'). Most of them are among the 10 most popular commercial cultivars (Bell et al., 1998; Deng et al., 2005) and have been used frequently as breeding parents for cultivar development. Their phenotype and inferred genotype for leaf blotching and vein color are shown in Table 1.

Flower induction, pollination, and progeny growing. Large, dry tubers $(6.4 \mathrm{~cm}$ or greater in diameter) were treated with a $\mathrm{GA}_{3}$ solution (ProGibb T\&O; Valent BioSciences, Libertyville, IL; $600 \mathrm{mg} \cdot \mathrm{L}^{-1}$ ) overnight at ambient temperature to induce flowers (Harbaugh and Wilfret, 1979). Treated tubers were planted in plastic pots $(20 \mathrm{~cm}$ in diameter, $3.5 \mathrm{~L}$ in volume) filled with VerGro container mix A (Verlite Company, Tampa, FL) in late Aug. 2004. Plants were maintained in a glasshouse with $20 \%$ to $30 \%$ light exclusion and temperatures between 15 and $32{ }^{\circ} \mathrm{C}$. Pollination was performed between 25 Oct. and 14 Nov. 2004 following the procedure of Deng and Harbaugh (2004). Seed heads were harvested in Dec. 2004 and Jan. 2005. Seeds were extracted and sown in Dec. 2004 and Jan. 2005 onto VerGrow container mix A (Verlite) in 200-cell trays and germinated at $\approx 21{ }^{\circ} \mathrm{C}$ under continuous cool fluorescent light $\left(30 \mu \mathrm{mol} \cdot \mathrm{m}^{-2} \cdot \mathrm{s}^{-1}\right)$. Between 14 Feb. and 1 Mar. 2005, seedlings were transferred to six-pack plastic cells filled with VerGrow container mix A (Verlite) amended with Nutricote 13-13-13 (13N6.4P-10.8K; The Scotts Co., Marysville, $\mathrm{OH})$. Seedlings were grown in a greenhouse with $20 \%$ to $30 \%$ light exclusion, a photosynthetic photon flux 600 to $800 \mu \mathrm{mol} \cdot \mathrm{m}^{-2} \cdot \mathrm{s}^{-1}$, and temperatures between 15 and $30{ }^{\circ} \mathrm{C}$. Progeny in the six-pack cells were planted on raised ground beds in June 2005. The soil was EauGallie fine sand with $\approx 1 \%$ organic matter and a $\mathrm{pH}$ of 6.2 to 6.8 . The beds were fumigated with methyl bromide and chloropicrin, covered with white-on-black plastic mulch, and irrigated with the seepage irrigation system (Geraldson et al., 1965). Plants were spaced $25.4 \mathrm{~cm}$ apart and grown on the beds for three seasons until July 2007. In each growing season, $15 \mathrm{~g}$ of Osmocote controlledrelease fertilizer $(18 \mathrm{~N}-2.6 \mathrm{P}-10 \mathrm{~K}, 8$ - to 9month; Scotts Co.) was applied to each plant.

Progeny of four crosses (or four populations) were also propagated asexually through tuber division and planted in four replicates in randomized complete blocks to assess potential variation in leaf characteristics after asexual propagation. Tuber pieces were planted in new fumigated, mulched ground beds between 3 May and 13 June 2007. These plants were irrigated and fertilized through a drip system.

Data-taking and analysis. Progeny was scored for leaf blotching (blotched or nonblotched) and main vein color (red, white, or green) in June to Nov. 2006 and again in June 2007. Each time, multiple fully expanded, mature leaves were examined for each progeny. Under high levels of light in the field or in the greenhouse, some white-veined leaves tended to develop some level of coloration. In these cases, young leaves before unfurling were examined to confirm vein color. Progeny of the four populations that were asexually propagated and replanted in 2007 were examined in Oct. 2007. Consistent phenotypes were observed among the four replicates of each progeny.

$\chi^{2}$ tests for goodness of fit were performed to compare observed ratios with expected ratios for the segregation of leaf blotching, whereas contingency $\chi^{2}$ tests were conducted to examine the possibility of genetic independence or linkage between leaf blotching and vein color. Calculation of the $\chi^{2}$ values was conducted using the program "Calculation for the Chi-Square Test" developed by Preacher (2008).

\section{Results and Discussion}

Inheritance of leaf blotching. Progeny from selfing three blotched cultivars, White Christmas, Carolyn Whorton (Fig. 1A), and

Table 1. Phenotype and genotype (inferred) of nine commercial caladium (Caladium $\times$ hortulanum) cultivars used as parents for crosses in this study.

\begin{tabular}{|c|c|c|c|c|}
\hline \multirow[b]{2}{*}{ Cultivar (abbreviation ${ }^{\mathrm{z}}$ ) } & \multicolumn{2}{|c|}{ Leaf blotching } & \multicolumn{2}{|c|}{ Color of main vein } \\
\hline & Phenotype & Genotype $^{y}$ & Phenotype & Genotype $^{x}$ \\
\hline Candidum (Can) & No & $b b$ & Green & $V^{g} V^{g}$ \\
\hline Carolyn Whorton (CW) & Yes & $B b$ & Red & $V^{\mathrm{r}} V^{\mathrm{g}}$ \\
\hline Fannie Munson (FM) & No & $b b$ & Red & - \\
\hline Florida Blizzard (FB) & Yes & $B b$ & White & $V^{w} V^{g}$ \\
\hline Frieda Hemple (FH) & No & $b b$ & Red & $V^{\mathrm{r}} V^{\mathrm{g}}$ \\
\hline Gingerland (Gin) & No & $b b$ & White & $V^{w} V^{g}$ \\
\hline Miss Muffet (MM) & No & $b b$ & White & $V^{w} V^{g}$ \\
\hline Rosebud (RB) & No & $b b$ & Red & $V^{\mathrm{r}} V^{\mathrm{w}}$ \\
\hline White Christmas (WC) & Yes & $B b$ & Green & $V^{\mathrm{g}} V^{\mathrm{g}}$ \\
\hline
\end{tabular}

${ }^{\mathrm{z}}$ Cultivar name abbreviation used in Tables 2 and 3.

y Inferred from this study.

'The genotype of 'Miss Muffet' for vein color is based on segregation data from this study (data not shown). The genotypes of other cultivars for vein color had been reported previously (Deng and Harbaugh, 2006; Deng et al., 2008). 'Fannie Munson' seemed to behave somewhat differently in leaf main vein color from other cultivars, and its genotype information for vein color was not available.
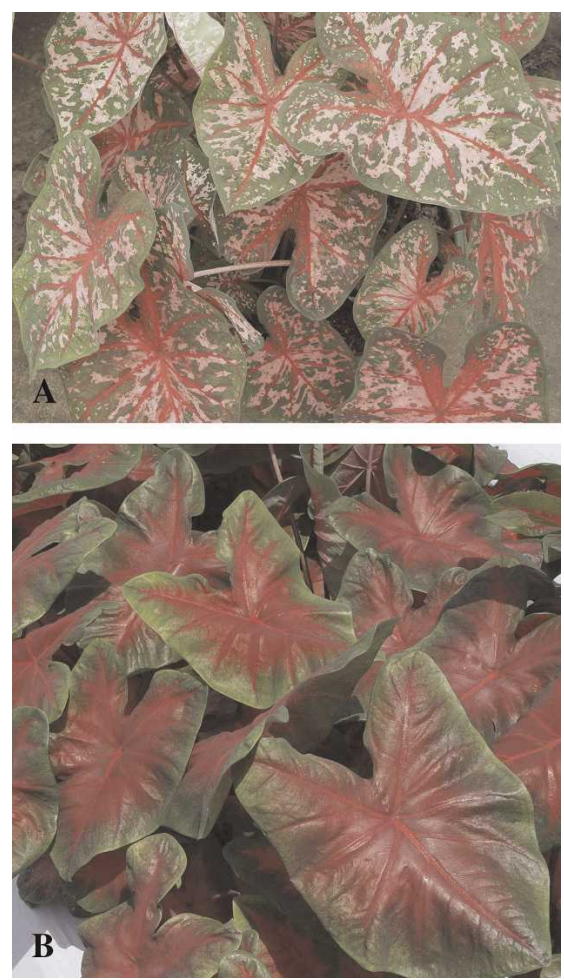

Fig. 1. Leaves of caladium cultivars Carolyn Whorton (A; blotched, red-veined) and Frieda Hemple (B; nonblotched, red-veined) showing the presence or absence of leaf blotching.

Florida Blizzard, segregated in a 3:1 ratio (blotched:nonblotched) (Table $2 ; \chi^{2}=0.11$ to $0.40, P=0.53$ to 0.74 ). Progeny from selfing three nonblotched cultivars (Candidum, Miss Muffet, and Gingerland) were all nonblotched (140 individuals; Table 2). These results indicate that leaf blotching seems to be controlled by one single nuclear locus with two alleles and that blotching allele was dominant over the nonblotching allele.

Five crosses were made between five nonblotched cultivars, including reciprocal crosses between 'Candidum' and 'Gingerland', 'Fannie Munson' and 'Gingerland', and a cross between 'Frieda Hemple' (Fig. 1B) and 'Rosebud'. None of the progeny (Table 2; 389 individuals) were blotched, indicating that these cultivars were homozygous-recessive for leaf blotching and might be good parents for test crosses.

Five test crosses were made to test the segregation of leaf blotching in 'White Christmas'. It was used as a seed parent in two crosses and as a pollen parent in three crosses. Leaf blotching segregated in a $1: 1$ ratio (Table $2 ; \chi^{2}=0.06$ to $2.13, P=0.14$ to $0.81)$ in the test crosses with 'Rosebud', 'Frieda Hemple', or 'Miss Muffet'. However, the segregation was skewed toward more nonblotched individuals in progeny of the reciprocal crosses between 'White Christmas' and 'Gingerland' (Table 2; $\chi^{2}=9.04$ or $6.40, P \leq 0.01$ ).

When 'Carolyn Whorton' was crossed with 'Gingerland' and 'Miss Muffet', the segregation of leaf blotching was in a $1: 1$ ratio (Table $2 ; \chi^{2}=0.10, P=0.75$ or 0.76 ) as 
Table 2. Segregation for leaf blotching in progeny of 20 caladium crosses made in $2004 .^{z}$

Cross

Female (genotype) $\times$ male parent (genotype)

$\overline{\mathrm{WC}^{\mathrm{w}}(B b) \otimes}$

$\mathrm{CW}(B b) \otimes$

$\mathrm{FB}(B b) \otimes$

Can $(b b) \otimes$

$\mathrm{MM}(b b) \otimes$

$\operatorname{Gin}(b b) \otimes$

Can $(b b) \times$ Gin $(b b)$

Gin $(b b) \times$ Can $(b b)$

$\mathrm{FM}(b b) \times \operatorname{Gin}(b b)$

Gin $(b b) \times \mathrm{FM}(b b)$

$\mathrm{FH}(b b) \times \mathrm{RB}(b b)$

$\mathrm{WC}(B b) \times \mathrm{RB}(b b)$

$\mathrm{MM}(b b) \times \mathrm{WC}(B b)$

$\mathrm{FH}(b b) \times \mathrm{WC}(B b)$

$\mathrm{WC}(B b) \times \mathrm{Gin}(b b)$

$\operatorname{Gin}(b b) \times \mathrm{WC}(B b)$

$\mathrm{CW}(B b) \times \operatorname{Gin}(b b)$

$\mathrm{CW}(B b) \times \mathrm{MM}(b b)$

$\mathrm{FB}(B b) \times \mathrm{CW}(B b)$

$\mathrm{FB}(B b) \times \operatorname{Gin}(b b)$

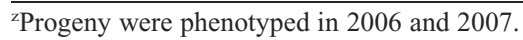

Progeny (no.)

\begin{tabular}{rcccc}
\hline $\begin{array}{c}\text { Blotched } \\
\left(B \_\right)^{\mathrm{y}}\end{array}$ & $\begin{array}{c}\text { Nonblotched } \\
(b b)^{\mathrm{y}}\end{array}$ & Ratio tested ${ }^{\mathrm{x}}$ & \multicolumn{2}{c}{ Chi square } \\
\cline { 5 - 6 } 29 & 12 & $3: 1$ & 0.40 & 0.53 \\
35 & 13 & $3: 1$ & 0.11 & 0.74 \\
63 & 23 & $3: 1$ & 0.14 & 0.71 \\
0 & 47 & $0: 1$ & & \\
0 & 14 & $0: 1$ & & \\
0 & 79 & $0: 1$ & & \\
0 & 94 & $0: 1$ & & \\
0 & 90 & $0: 1$ & & \\
0 & 89 & $0: 1$ & & \\
0 & 87 & $0: 1$ & & \\
0 & 29 & $0: 1$ & & 0.81 \\
34 & 32 & $1: 1$ & 0.06 & \\
53 & 39 & $1: 1$ & 2.13 & 0.14 \\
4 & 3 & $1: 1$ & 0.14 & 0.71 \\
32 & 61 & $1: 1$ & 9.04 & $<0.01$ \\
33 & 57 & $1: 1$ & 6.40 & 0.01 \\
49 & 46 & $1: 1$ & 0.10 & 0.76 \\
44 & 47 & $1: 1$ & 0.10 & 0.75 \\
45 & 16 & $3: 1$ & 0.05 & 0.82 \\
34 & 59 & $1: 1$ & 6.72 & 0.01 \\
\hline
\end{tabular}

${ }^{\mathrm{y}}$ Genotype for each of the two phenotypes, blotched or nonblotched. There were two possible genotypes ( $B B$ or $B b$, as indicated by $B_{-}$) for the blotched progeny, but one genotype $(b b)$ for the nonblotched progeny.

${ }^{x}$ Segregation ratios expected for traits controlled by single dominant nuclear genes

${ }^{\mathrm{w}}$ Cultivar name abbreviation. Refer to Table 1 for complete name.

expected for a trait controlled by a single nuclear locus with complete dominance. This segregation was also observed when 'Florida Blizzard' and 'Carolyn Whorton' were crossed (Table $2 ; \chi^{2}=0.05, P=0.82$ ). However, skewed segregation (Table $2 ; \chi^{2}=6.72, P=$ $0.01)$ was observed again when the cross involves 'Gingerland'. In this case, more blotched progeny appeared than expected.

In summary, results suggest that leaf blotching in caladium is controlled by a single nuclear locus. We propose to name this locus $B$ with allele $B$ for blotching and having complete dominance over the nonblotching allele $b$. The three major blotched cultivars, White Christmas, Carolyn Whorton, and Florida Blizzard, are all heterozygous $(\mathrm{Bb})$ at this locus. The skewed segregation in crosses involving 'Gingerland' as seed or the pollen parent might indicate the existence of other factors and/or mode of gene interaction that influenced the expression of leaf blotching.

Genetic relationship between leaf blotching and vein color. Previous results show that the color of the main vein in caladium is controlled by three alleles at the $V$ locus (red vein allele $V^{\mathrm{r}}>$ white vein allele $V^{\mathrm{w}}>$ green vein allele $V^{\mathrm{g}}$ ) (Deng and Harbaugh, 2006; Wilfret, 1983, 1986). In the cross 'White Christmas' (green-veined, $V^{\mathrm{g}} V^{\mathrm{g}}$ ) and 'Rosebud' (red-veined, $V^{\mathrm{r}} V^{\mathrm{w}}$ ), four types of progeny (red-veined blotched or nonblotched and white-veined blotched or nonblotched) segregated in a 1:1:1:1 ratio (Table 3; $\left.\chi^{2}=1.96, P=0.58\right)$. The cross 'Miss Muffet' (white-veined, $V^{\mathrm{w}} V^{\mathrm{g}}$ ) and 'White Christmas' had another four types of progeny (whiteveined blotched or nonblotched and greenveined blotched or nonblotched) in a $1: 1: 1: 1$ ratio (Table $3 ; \chi^{2}=1.75, P=0.63$ ). In these two crosses, both independent segregation and complete linkage between the two concerning traits could result in the observed segregation ratio (Table 3 ).

Three types of progeny were observed in the 'Carolyn Whorton' (red-veined, $V^{\mathrm{r}} V^{\mathrm{g}}$ ) $\times$ self progeny with the double-recessive (green-veined, nonblotched; $V^{\mathrm{g}} V^{\mathrm{g}} b b$ ) type missing (Table 3). $\chi^{2}$ analysis indicates a greater probability for linkage between leaf blotching and vein color $\left(\chi^{2}=0.79, P=0.85\right)$ than for independent segregation $\left(\chi^{2}=6.89\right.$, $P=0.08)$. A similar segregation pattern (three types of progeny and with doublerecessive progeny missing) appeared when 'White Christmas' and 'Carolyn Whorton' were crossed, which rejects an independent segregation hypothesis (Table $3 ; \chi^{2}=43.67$, $P=0$ ) but fit the ratio expected for complete linkage between the two loci in the repulsion phase (Table $3 ; \chi^{2}=3.54, P=0.32$ ). The segregation of three types of progeny in the cross 'Carolyn Whorton' and 'Miss Muffet' also supports linkage between leaf blotching and vein color (Table $3 ; \chi^{2}=4.41, P=0.49$ ). If the two traits were inherited independently, six types of progeny (three vein colors and blotching or nonblotching) should be in a ratio of 2 (red-veined, blotched):2 (red-veined, nonblotched):1 (white-veined, blotched):1 (white-veined, nonblotched):1 (green-veined, blotched):1 (green-veined, nonblotched) in this cross. Segregation ratios in the 'Florida Blizzard' $\times$ self or 'Florida Blizzard' $\times$ 'Carolyn Whorton' also supported genetic

Table 3. Joint segregation of leaf blotching (blotched and nonblotched) and main vein color (red, white, and green) in progeny of seven caladium crosses.

\begin{tabular}{|c|c|c|c|c|c|c|c|c|c|c|c|c|c|}
\hline \multirow{5}{*}{$\begin{array}{l}\text { Cross: seed } \\
\text { parent }(\text { genotype }) \times \text { pollen } \\
\text { parent }(\text { genotype })\end{array}$} & \multirow{2}{*}{\multicolumn{7}{|c|}{ Progeny (no.) }} & \multicolumn{6}{|c|}{ Inheritance model tested } \\
\hline & & & & & & & & \multicolumn{3}{|c|}{ Independent inheritance } & \multicolumn{3}{|c|}{ Complete linkage } \\
\hline & \multirow[b]{3}{*}{ Total } & \multicolumn{2}{|c|}{$\operatorname{Red}\left(V_{-}^{\mathrm{r}}\right)^{\mathrm{z}}$} & \multicolumn{2}{|c|}{ White $\left(V^{\mathrm{w}}\right)^{\mathrm{z}}$} & \multicolumn{2}{|c|}{ Green $\left(V^{\mathrm{g}} V^{g}\right)^{\mathrm{z}}$} & \multirow{3}{*}{$\begin{array}{l}\text { Expected } \\
\text { ratio }\end{array}$} & \multirow{2}{*}{\multicolumn{2}{|c|}{ Chi square }} & \multirow{3}{*}{$\begin{array}{l}\text { Expected } \\
\text { ratio }\end{array}$} & \multirow{2}{*}{\multicolumn{2}{|c|}{ Chi square }} \\
\hline & & \multirow{2}{*}{$\begin{array}{c}\mathrm{B} \\
\left(B_{-}\right)^{\mathrm{y}}\end{array}$} & \multirow{2}{*}{$\begin{array}{c}\mathrm{N} \\
(b b)^{\mathrm{y}}\end{array}$} & \multirow{2}{*}{$\begin{array}{c}\mathrm{B} \\
\left(B_{-}\right)^{\mathrm{y}}\end{array}$} & \multirow{2}{*}{$\begin{array}{c}\mathrm{N} \\
(b b)^{\mathrm{y}}\end{array}$} & \multirow{2}{*}{$\begin{array}{c}\mathrm{B} \\
\left(B_{-}\right)^{\mathrm{y}}\end{array}$} & \multirow{2}{*}{$\begin{array}{c}\mathrm{N} \\
(b b)^{\mathrm{y}}\end{array}$} & & & & & & \\
\hline & & & & & & & & & $\chi^{2}$ & $P$ & & $\chi^{2}$ & $P$ \\
\hline $\mathrm{WC}^{\mathrm{x}}\left(V^{\mathrm{g}} b / / V^{\mathrm{g}} B\right) \times \mathrm{RB}$ & & & & & & & & & & & & & \\
\hline$\left(V^{\mathrm{r}} b / / V^{\mathrm{w}} b\right)$ & 67 & 15 & 13 & 19 & 20 & & & $1: 1: 1: 1$ & 1.96 & 0.58 & $1: 1: 1: 1$ & 1.96 & 0.58 \\
\hline $\mathrm{MM}\left(V^{\mathrm{w}} b / / V^{\mathrm{g}} b\right) \times \mathrm{WC}$ & & & & & & & & & & & & & \\
\hline$\left(V^{\mathrm{g}} b / / V^{\mathrm{g}} B\right)$ & 94 & & & 25 & 20 & 28 & 21 & $1: 1: 1: 1$ & 1.75 & 0.63 & $1: 1: 1: 1$ & 1.75 & 0.63 \\
\hline $\mathrm{CW}\left(V^{\mathrm{r}} b / / V^{\mathrm{g}} B\right) \otimes$ & 48 & 21 & 13 & & & 14 & 0 & $9: 3: 3: 1$ & 6.89 & 0.08 & $2: 1: 1: 0$ & 0.79 & 0.85 \\
\hline $\begin{array}{l}\mathrm{WC}\left(V^{\mathrm{g}} b / / V^{\mathrm{g}} B\right) \times \mathrm{CW} \\
\quad\left(V^{\mathrm{r}} b / / V^{\mathrm{g}} B\right)\end{array}$ & 71 & 13 & 24 & & & 34 & 0 & $3: 1: 3: 1$ & 43.67 & 0 & $1: 1: 2: 0$ & 3.54 & 0.32 \\
\hline $\begin{array}{c}\mathrm{CW}\left(V^{\mathrm{r}} b / / V^{\mathrm{g}} B\right) \times \mathrm{MM} \\
\left(V^{\mathrm{w}} b / / V^{\mathrm{g}} b\right)\end{array}$ & 91 & 0 & 47 & 15 & 0 & 29 & 0 & $2: 2: 1: 1: 1: 1$ & 99.81 & 0 & $0: 2: 1: 0: 1: 0$ & 4.41 & 0.49 \\
\hline $\mathrm{FB}\left(V^{\mathrm{w}} b / / V^{\mathrm{g}} B\right) \otimes$ & 86 & & & 39 & 23 & 24 & 0 & $9: 3: 3: 1$ & 13.97 & $<0.01$ & $2: 1: 1: 0$ & 0.77 & 0.86 \\
\hline $\begin{array}{l}\mathrm{FB}\left(V^{\mathrm{w}} b / / V^{\mathrm{g}} B\right) \times \mathrm{CW} \\
\quad\left(V^{\mathrm{r}} b / / V^{\mathrm{g}} B\right)\end{array}$ & 61 & 19 & 16 & 11 & 0 & 15 & 0 & $6: 2: 3: 1: 3: 1$ & 18.61 & $<0.01$ & $1: 1: 1: 0: 1: 0$ & 2.15 & 0.83 \\
\hline
\end{tabular}

zPhenotype and genotype (in parentheses) for color of leaf main vein. Caladium vein color is controlled by one locus with three alleles, $V^{\mathrm{r}}, V^{\mathrm{w}}$, and $V^{\mathrm{g}}$ for red, white, and green vein, respectively (Deng and Harbaugh, 2006). The order of dominance among them is: $V^{\mathrm{r}}>V^{\mathrm{w}}>V^{\mathrm{g}}$. Therefore, there are three possible genotypes $\left(V^{\mathrm{r}} V^{\mathrm{r}}, V^{\mathrm{r}} V^{\mathrm{w}}\right.$, and $\left.V^{\mathrm{r}} V^{\mathrm{g}}\right)$ for red-veined progeny, two possible genotypes $\left(V^{\mathrm{w}} V^{\mathrm{w}}\right.$ and $\left.V^{\mathrm{w}} V^{\mathrm{g}}\right)$ for white-veined progeny, and one genotype $\left(V^{\mathrm{g}} V^{\mathrm{g}}\right)$ for green-veined progeny.

yPhenotype and genotype (in parentheses) for leaf blotching. There were two possible genotypes ( $B B$ or $B b$, as indicated by $B \_$) for blotched (B) progeny, but one genotype $(b b)$ for nonblotched $(\mathrm{N})$ progeny.

${ }^{\mathrm{x}}$ Cultivar name abbreviation. Refer to Table 1 for complete name. 
linkage between leaf blotching and vein color $(P=0.86$ and 0.83$)$ and rejected independent segregation between the two traits (Table 3 ).

Thus, segregation data from all the five crosses that could differentiate genetic linkage from independent inheritance support complete (or close) linkage between leaf blotching and vein color with the red $\left(V^{r}\right)$ or white $\left(V^{\mathrm{w}}\right)$ vein alleles in coupling with the nonblotching allele $b$ and the green vein allele $V^{\mathrm{g}}$ in coupling with the blotching allele $B$. Thus, the genotype for 'Carolyn Whorton', 'White Christmas', and 'Florida Blizzard' in vein color and leaf blotching would be $V^{\mathrm{r}} b / / V^{\mathrm{g}} B, V^{\mathrm{g}} b / /$ $V^{\mathrm{g}} B$, and $V^{\mathrm{w}} b / / V^{\mathrm{g}} B$, respectively. Collectively, 357 progeny were examined in the five crosses, and no double-recessive recombinants were observed. This suggests very tight linkage between leaf blotching and vein color.

As mentioned earlier, because of the potential ornamental values, developing new blotched cultivars has been an important objective in caladium breeding. The information gained from this study may help plan parental crosses and breeding populations for this breeding objective. These results indicate that new blotched progeny or breeding lines can be obtained if one of the two breeding parents in a given cross is blotched. All three blotched cultivars tested in this study ('Carolyn Whorton', 'White Christmas', and 'Florida Blizzard') are heterozygous for leaf blotching. Several other commercially available blotched cultivars, including Florida Calypso, Florida Elise, and Florida Roselight, are progeny of 'Carolyn Whorton' and nonblotched cultivars (Wilfret, 1992, 1995). These cultivars are expected to be heterozygous for leaf blotching as well. When one of these cultivars is crossed with nonblotched cultivars, approximately half of the progeny is likely to express leaf blotching. When these blotched cultivars are crossed, three-fourths of their progeny are likely to be blotched. Therefore, a significant percentage of blotched progeny will appear in a breeding population derived from crossing blotched cultivars or crossing blotched cultivars with nonblotched cultivars. This high percentage of blotched progeny should facilitate developing new blotched cultivars with diverse leaf colors, shapes, and growth habits and improved stress (sunburn, cold, drought, and so on) tolerance and disease resistance \{Fusarium [Fusarium solani (Mart.) Saa.] tuber rot, for example\}.

The available information on the mode of inheritance of leaf blotching may also provide a basis for further investigation into the origin of this trait. Leaf blotching is intriguing in cultivated caladium. The trait occurs commonly in Caladium humboldtii Schott, but it has been observed only rarely in the species accessions of C. bicolor, C. marmoratum, C. picturatum, or C. schomburgkii that are believed to have contributed to the development of cultivated caladium (C. $\times$ hortulanum)
(Birdsey, 1951; Hayward, 1950; Wilfret, 1993). It was suspected that $C$. humboldtii might be part of the parentage of 'White Christmas' and contributed to the leaf blotching trait. However, molecular marker and genetic relationship analysis indicate that 'White Christmas' and C. humboldtii were not closely related (Deng et al., 2007). Demonstration of leaf blotching as a trait under the control of a single dominant nuclear allele may facilitate future efforts to tag the trait with molecular markers and potentially trace the species origin of leaf blotching.

A previous study showed that leaf spotting is linked to vein color at an average recombination frequency of $4.4 \%$ (Deng et al., 2008). Considering such, one may ask what are the genetic or linkage relationships between these three traits (vein color, leaf spotting, and leaf blotching)? Efforts are being made to identify plant materials with appropriate phenotypes and genotypes for these traits and to develop appropriate families to investigate the question.

Ornamental aroids are the most prominent plants used in the foliage plant industry (Henny, 1988; Henny and Chen, 2003). Leaf characteristics are one of the most important groups of traits for the commercial values of ornamental aroids. A thorough understanding of the inheritance of foliar traits is critical for improving breeding efficiency for producing desirable cultivars in these aroids (Henny, 1988). Studies to date on the inheritance of foliar traits in caladium (leaf shape, vein color, spotting, blotching, and so on) have shown that the traits are generally under simple genetic control (Deng and Harbaugh, 2006; Deng et al., 2007, 2008; Gager, 1991; Wilfret, 1983, 1986). Diverse variation is available in a number of other leaf characteristics in caladium (Deng, personal observations). It will be interesting to determine how these other foliar traits are genetically controlled. If these traits are also under simple genetic control, caladium may serve as a good model for investigating the genetic relationships among foliar traits and studying the genetic interactions among the underlying loci in ornamental aroids.

\section{Literature Cited}

Bell, M.L., G.J. Wilfret, and D.A. Devoll. 1998. Survey of caladium tuber producers for acreage of cultivars grown. Proc. Fla. State Hort. Soc. 111:32-34.

Birdsey, M.R. 1951. The cultivated aroids. The Gillick Press, Berkeley, CA.

Darlington, C.D. and A.P. Wylie. 1955. Chromosome atlas of flowering plants. George Allen and Unwin Ltd. London, UK.

Deng, Z., F. Goktepe, and B.K. Harbaugh. 2007. Assessment of genetic diversity and relationships among caladium cultivars and species using molecular markers. J. Amer. Soc. Hort. Sci. 132:219-229.
Deng, Z., F. Goktepe, and B.K. Harbaugh. 2008. Inheritance of leaf spots and their genetic relationships with leaf shape and vein color in caladium. J. Amer. Soc. Hort. Sci. 133:78-83.

Deng, Z. and B.K. Harbaugh. 2004. Technique for in vitro pollen germination and short-term pollen storage in caladium. HortScience 39: 365-367.

Deng, Z. and B.K. Harbaugh. 2006. Independent inheritance of leaf shape and main vein color in caladium. J. Amer. Soc. Hort. Sci. 131:53-58.

Deng, Z., B.K. Harbaugh, R.K. Schoellhorn, and R.C. Andrew. 2005. 2003 survey of the Florida caladium tuber production industry. Fla. Coop. Ext. Serv., Inst. Food Agr. Sci., Univ. Fla. extension fact sheet ENH 1007. 16 May 2008. $<$ http://edis.ifas.ufl.edu/EP258>.

Evans, M.R., G.J. Wilfret, and B.K. Harbaugh. 1992. Caladiums as potted and landscape plants. Fla. Coop. Ext. Serv., Inst. Food Agr. Sci., Univ. Fla. extension fact sheet CIR1060. 30 Apr. 2008. <http://edis.ifas.ufl.edu/MG278>.

Gager, C.R. 1991. Leaf spot color and venation pattern inheritance in Caladium. Univ. Fla. Gainesville. PhD Diss.

Geraldson, C.M., A.J. Overman, and J.P. Jones. 1965. Combination of high analysis fertilizers, plastic mulch and fumigation for tomato production on old agricultural land. Proc. Soil Crop Sci. Soc. Fla. 25:18-24.

Harbaugh, B.K., B.D. Miranda, and G.J. Wilfret. 2002. 'Florida Blizzard'-A white fancyleaved caladium for large pots or shady landscapes. HortScience 37:844-846.

Harbaugh, B.K. and G.J. Wilfret. 1979. Gibberellic acid $\left(\mathrm{GA}_{3}\right)$ stimulates flowering in Caladium hortulanum Birdsey. HortScience 14:72-73.

Hayward, W. 1950. Fancy-leaved caladiums. Plant Life 6:131-142.

Henny, R.J. 1982. Inheritance of foliar variegation in two Dieffenbachia cultivars. J. Hered. 73:384.

Henny, R.J. 1983. Inheritance of the white foliar midrib in Dieffenbachia and its linkage with the gene for foliar variegation. J. Hered. 74:483484.

Henny, R.J. 1986. Single locus, multiallelic inheritance of foliar variegation in Aglaonema. J. Hered. 77:214-215.

Henny, R.J. 1988. Ornamental aroids: Culture and breeding. Hort. Rev. 10:1-33.

Henny, R.J. and J. Chen. 2003. Cultivar development of ornamental foliage plants. Plant Breed. Rev. 23:245-290.

Preacher, K.J. 2008. Calculation for the chi-square test: An interactive calculation tool for chisquare tests of goodness of fit and independence. 24 Jan. 2008. <http://www.psych.ku.edu/ preacher/chisq/chisq.htm>.

Wilfret, G.J. 1983. Inheritance of vein color in caladium leaves. HortScience 18:610 (abstr.).

Wilfret, G.J. 1986. Inheritance of leaf shape and color patterns in Caladium (Araceae). HortScience 21:750 (abstr.)

Wilfret, G.J. 1992. 'Florida Roselight' caladium. HortScience 27:1054-1056.

Wilfret, G.J. 1993. Caladium, p. 239-247. In: de Hertogh, A. and M. le Nard (eds.). The physiology of flower bulbs. Elsevier, New York, NY.

Wilfret, G.J. 1995. 'Florida Calypso': A multicolored caladium for the landscape and containers. HortScience 30:777 (abstr.). 